\title{
Congress accused of slighting sound science
}

\section{Mark Schrope}

The law passed by the US Congress in 1996 allowing it to overthrow expensive government regulations was supposed to ensure that any such rules were underpinned by "sound science".

But last week Congress was being accused of ignoring such science, when both houses used the law to throw out rules governing ergonomics in the workplace. Developed by the Occupational Safety and Health Administration (OSHA), the rules were aimed at reducing repetitive-motion injuries by requiring employers to apply the latest ergonomics research.

Supporters of the OSHA regulations claimed that in repealing the rules, Congress was brazenly disregarding the scientific consensus reached in a report on ergonomics, which was published in January by the National Academy of Sciences (NAS).

House minority leader Richard Gephardt (Democrat, Missouri) thinks that the message in the NAS report is clear. "This is a critical issue affecting hundreds of thousands of workers every year," he told the Congress, "and government needs to act in the name of their safety."

The OSHA rules had been under development for a decade before they became effective on 16 January this year. They called for workers to be educated about the dangers

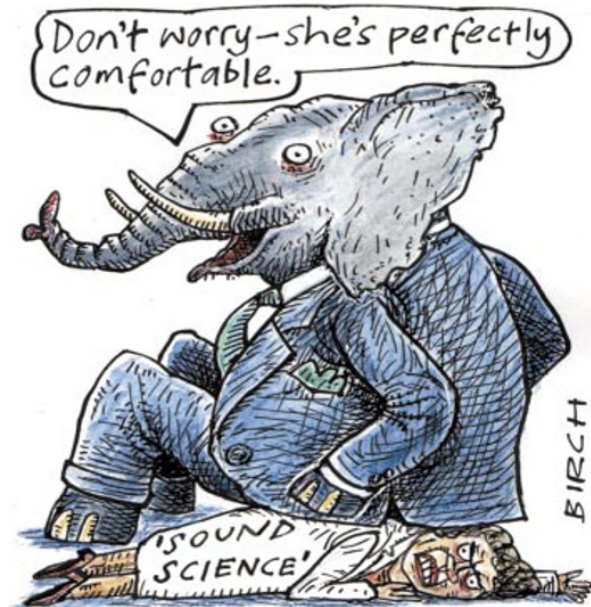

of repetitive-motion tasks such as heavy lifting, operating vibrating equipment and typing. Under certain conditions, they also required employers to alter job specifications so that the tasks fell within established guidelines for injury prevention.

Many businesses and Republicans protested against the rules, saying that they could cost over $\$ 100$ billion to implement. The OSHA estimated costs at $\$ 4.5$ billion, but claimed that the rules would save companies over $\$ 9$ billion through increased productivity.

The Congressionally mandated NAS study, "Musculoskeletal Disorders and the
Workplace: Low Back and Upper Extremities", did not explicitly assess the OSHA rules. But it concluded that repetitive-motion tasks significantly increase risks for certain injuries, and that proper intervention can reduce such risks.

"The whole action of repealing really shows a disregard for the science," says Jonathan Stivers, a spokesman for Representative Nancy Pelosi (Democrat, California), a supporter of the rules. The NAS report "clearly justifies the need" for the new rules, he adds.

Republicans and the handful of Democrats who defeated the rules say that they agree ergonomic problems should be dealt with, but that the rules were poorly designed. "They were just too far-reaching, and were going to be a huge burden on business and industry and cause a lot more problems than they would correct," says Dan Lara, a spokesman for the House Committee on Education and the Workforce.

"My sense of what's happening at the moment is that the [NAS] report is being largely put aside and other agendas are being pursued," says Jeremiah Barondess, president of the New York Academy of Medicine and chair of the panel that produced the NAS report. "The science is there. The science is clear. You can like it or you can not like it, but that's what it is."

\section{Mine mooted as underground home for physicists}

\section{Rex Dalton, San Diego}

A gold mine in the Black Hills of South Dakota has been selected as the most likely US site for a proposed national underground physics laboratory.

The laboratory, which would cost between \$70 million and \$150 million to build, would be used for highly sensitive experiments in neutrino physics and for other physics experiments that must be conducted away from cosmic rays. Currently, US physicists must travel to the Super-Kamiokande facility at Tsukuba Science City, Japan, or Italy's Gran Sasso Laboratories near Rome to participate in such experiments.

As part of an exploratory effort supported jointly by the National Science Foundation and the Department of Energy, a committee of experts looked at five proposed sites before recommending the Homestake Mine - where the University of Pennsylvania has already conducted some experiments - as the most promising.

Scheduled to close as a working mine this autumn, the 125-year-old Homestake is economically attractive, as the necessary access tunnels are already in place. But it also presents certain logistical challenges, because of limitations on the size of equipment that can be transported down its 2,500-metre-deep shafts.

The South Dakota School of Mines and Technology at Rapid City was involved in proposing the Homestake site, both to boost science in the region and as a national resource. But any laboratory that evolves will encompass a broad range of researchers and institutions.

Proponents of the new facility would like to expedite planning so that deep-mine experts can remain on site when the mine closes. But the National Science Foundation and the Department of Energy may struggle to find money for the proposal. The project has yet to be reviewed by agency officials, and state and federal legislation would be needed for the government to assume liability for the mine from its current owners.

Although the panel favoured the South Dakota site, it also recommended environmental assessments of several alternatives in California and Nevada.

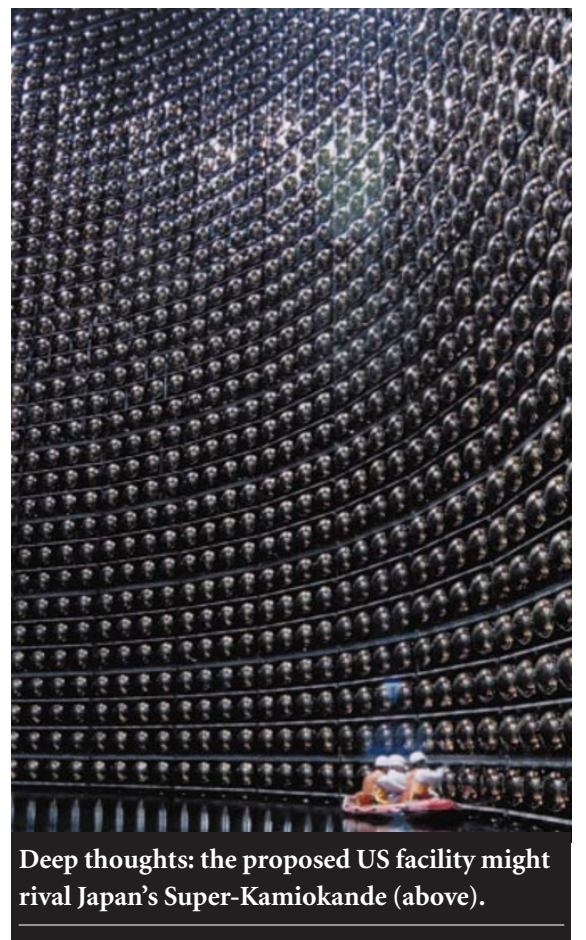

NATURE|VOL 410| 15 MARCH 2001 |www.nature.com 